\title{
Yerleşik Tarım Çalışanlarının Zirai İlaçlama ve İș Kazaları ile İlgili Bilgi, Tutum ve Davranışlarının Değerlendirilmesi
}

Evaluation of Resident Agricultural Workers Knowledge, Attitudes and Behaviors about Agricultural Pesticide and Occupational Accidents

\author{
Mehmet Doğan ${ }^{1}$, Muhammet Bayraktar², Muhsin Akbaba ${ }^{3}$ \\ ${ }^{1}$ Erciyes Üniversitesi Halil Bayraktar Sağlık Hizmetleri Meslek Yüksekokulu / Kayseri \\ ${ }^{2}$ Niğde Çiftlik Divarlı Aile Sağlı̆̆ı Merkezi / Niğge \\ ${ }^{3}$ Çukurova Üniversitesi Tip Fakültesi Halk Sağh̆ğı / Adana
}

Yazışma Adresi / Correspondence:

Mehmet Doğan

Erciyes Üniversitesi Halil Bayraktar Sağık Hizmetleri Meslek Yüksekokulu / Kayseri

T: +90352 2076666 / Dahili:40014 E-mail : mehmetdogan@erciyes.edu.tr

Geliş Tarihi / Received : 17.06.2019 Kabul Tarihi / Accepted : 07.11.2019

Orcid :

Mehmet Doğan https://orcid.org/: 0000-0002-2971-7246 Muhammet Bayraktar https://orcid.org/0000-0003-2242-8046

Muhsin Akbaba https://orcid.org/0000-0003-3028-6698

( Sakarya Tip Dergisi / Sakarya Med J 2019, 9(4):632-638 ) DOI: 10.31832/smj.578803

** 04-08 Mart 2018 tarihleri arasında Antalya’da düzenlenen "2. Uluslararası Mesleksel ve Çevresel Hastalıklar " kongresinde " Yerleşik Tarım Çalışanlarının Zirai İlaçlama ve İș Kazaları ile İlgili Bilgi, Tutum ve Davranıșlarının Değerlendirilmesi" Oral Presentation (Sözlü Sunum) olarak sunulmuștur.

Öz

Amaç Bu çalıșma, Niğde ili Çiftlik ilçesinde yerleșik olarak tarım ișçiliği yapanlarda iş kazası geçirme durumunu belirlemek, iș kazası ve zirai ilaçlama ilgili bilgi, tutum ve davranışlarını değerlendirmek amacıyla yapılmıştır. Gereç ve Tanımlayıcı ve kesitsel nitelikteki bu çalışma, 2017 yllı Temmuz-Eylül ayları arasında çalışmaya katılmayı kabul eden 197 kişi üzerinde gerçekleştirilmiştir. Katılımcılara, sosyo-demografik özelliklerine ve çalışma yaşamına yönelik 43 sorudan oluşan anket formu yüz yüze görüşme yöntemi ile uygulanmıștır.

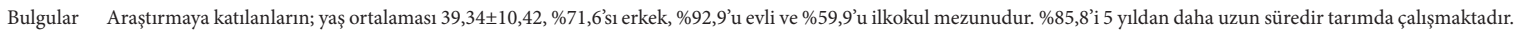
İlaçlama esnasında \%13,4’ü maske, $\% 51,5$ ’i eldiven takarken, $\% 15,7$ 'si saçlarını kapatmakta ve $\% 5,2$ 'si tulum giymektedir. İlaçlamadan sonra \%17,9’u ellerini ve yüzünü yıkarken, \%34,3’ü dus almakta, \%10,4'ü kıyafetlerini ayrı yıkamakta ve \%9,7’si ise hiçbir önlem almamaktadır. Çalısma esnasında kaza geçirenlerin oranı \%17,3'dür. Bu kazaların \%63,9'u motorlu tarım makinelerinin kullanımında ve elle kullanılan basit aletler sonucunda olmuștur ve \%7,1'inde kalıcı bir durum oluşmuştur. Çalışırken kaza/ hastalık durumu olanların sadece \%20,3’ü sağlık kuruluşuna başvurmakta ve başvurmama nedenleri \%24,4 vakitsizlik, \%94,7 önemsememedir. Kaza/yaralanma sonucu aşı olup olmadığını hatırlamayanların oranı \%19,8 iken, aşı olduğunu belirten yoktur. En sık kaza nedeni olarak; \%92,9 dikkatsizlik ve \%50,3 yapılan iş hakkında bilgisizlik belirtilmiştir. Sadece \%3,6’sı yapılan işle ilgili önceden bir eğitim almıştır.

Sonuç Yerleșik tarım çalışanlarının büyük çoğunluğu erkeklerden $(\% 71,6)$ oluşmaktadır. Kadınlarda $(\% 37,5)$ iş kazası geçirme sıklığı daha fazladır. İş kazalarının tamamı tarımda çalışma yılı 5 yıl ve üzeri olan çalışanlarında gerçekleşmiştir. İs sağlığı ve güvenliği ile ilk yardım eğitimi alan tarım çalışanların sayısı oldukça düşüktür.

Anahtar Eğitim; İş Sağlığı; Tarımsal İlaçlama; Yerleşik Tarım Çalışanı

kelimeler

Abstract

Objective This study was carried out with the aim of investigating the occupational accidents and pesticides the knowledge, attitudes and behaviors of established agricultural workers who came to work in Çiftlik district of Niğde province.

Materials This descriptive, cross-sectional study was conducted in a village and a town in Niğde province's Çiftlik district between July-September 2017 with 197 people who accepted participating and Methods by filling a questionnaire. A questionnaire consisting of 43 questions about the socio-demographic characteristics and working life of the participants was administered through face-to-face interview method.

Results Average age of participants is $39.34 \pm 10.43$ years, $71.6 \%$ male, $92.9 \%$ married $59.9 \%$ are primary school graduates. $85.8 \%$ are farmers for $5+$ years. During the spraying; $13.4 \%$ wearing mask, $51.5 \%$ using gloves, $15.7 \%$ covering their hair and $5.2 \%$ wearing a work wear. $17.3 \%$ suffered from work accidents, $63.9 \%$ of those happened using motorized agricultural machinery and hand tools and $7.1 \%$ were permanent injuries. Only $20.3 \%$ of those having an accident $/$ illness during work are applying to a health institution and reason for not applying are $94.7 \%$ disregard. None indicated getting vaccinated after accident/injury, $19.8 \%$ don't even remember. Risks encountered while working are $71.2 \%$ dust, $65.2 \%$ weight, 39.1\% noise; while $86.8 \%$ gloves and $71.1 \%$ hats are used for protection. The most frequent cause of accidents is $92.9 \%$ inattention and $50.3 \%$ ignorance. Only $3.6 \%$ had pre-work and first aid trainings.

Conclusion The majority of resident agricultural workers are men (71.6\%). The incidence of occupational accidents is higher in women (37.5\%). All of the occupational accidents occurred in the employees whose agricultural year was 5 years or more. The number of agricultural workers receiving occupational health and safety and first aid training is quite low.

Key words Education; Occupational Health; Pesticides; Resident Agricultural Worker 


\section{GIIRIŞ}

Tarım, insanoğlunun beslenme, giyim gibi en temel gereksinimlerini karşıladığından dolayı yaşam devam ettiği sürece önemini her zaman koruyacak bir alan ve sektördür. ${ }^{1}$ Dünyadaki hızlı nüfus artışı, gıda ihtiyacının artmasına ve buna paralel olarak da tarım sektörünün öneminin daha da artmasına neden olacaktır. ${ }^{2-3}$

Türkiye İstatistik Kurumu (TÜİK) 2018 verilerine göre; Türkiye 77,9 milyon hektar olan toprak varlığının, yaklaşık 23,2 milyon hektarını tarım arazileri oluşturmaktadır. ${ }^{4}$ 2018 yılı Adrese Dayalı Nüfus Kayıt Sistemi Sonuçlarına (ADNKS) göre; nüfusun \%92,3'ü il ve ilçe merkezlerinde ikamet ederken, \%7,7'si belde ve köylerde yaşamaktadır. ${ }^{5}$

TÜİK 2019 Şubat dönemi sonuçlarına göre, tarımda istihdam edilen nüfus 4,7 milyon olup, toplam istihdam içerisindeki payı \%17,1'dir. ${ }^{6}$ Tarımda istihdam edilen bu nüfusu kendi hesabına çalışan ücretsiz aile işçileri ile daimi ve geçici tarım işçileri ağırlıklı olarak oluşturmaktadır. ${ }^{3}$

Birleşmiş Milletler Gıda ve Tarım Örgütü (FAO) zirai ilaçlama ürünlerini (pestisit); "Tarım ürünlerine ve hayvansal gıdalara üretim, hasat, depolama ve taşıma esnasında zarar veren herhangi bir zararlıyı (zararlı ot dahil) kontrol etmek, bunların zararlarını önlemek üzere uygulanan maddelerdir. Ayrıca hayvanların vücutlarında bulunan herhangi bir böcek veya zararlının kontrolü amacıyla hayvanlara verilen maddeler" olarak tanımlamaktadır. ${ }^{7}$

5510 sayılı Sosyal Sigortalar ve Genel Sağlık Sigortası Kanununun 13 üncü maddesinde iş kazası;

a) Sigortalının işyerinde bulunduğu sırada,

b) İşveren tarafından yürütülmekte olan iş nedeniyle veya görevi nedeniyle, sigortalı kendi adına ve hesabına bağımsız çalışıyorsa yürütmekte olduğu iş veya çalışma konusu nedeniyle işyeri dışında,

c) Bir işverene bağlı olarak çalışan sigortalının, görevli olarak işyeri dışında başka bir yere gönderilmesi nedeniyle asıl işini yapmaksızın geçen zamanlarda,

d) Emziren kadın sigortalının, çocuğuna süt vermek için ayrilan zamanlarda,

e) Sigortalıların, işverence sağlanan bir taşıtla işin yapıldığı yere gidiş gelişi sırasında, meydana gelen ve sigortalıyı hemen veya sonradan bedenen ya da ruhen özre uğratan olay olarak tanımlamaktadır. ${ }^{8}$

Uluslararası Çalışma Örgütü (ILO) verilerine göre dünyada her yıl meydana gelen 355 bin ölümlü iş kazasının 170 bini tarım sektöründe görülmektedir. ILO, 2013 verilerine göre dünyada tüm sektörler itibariyle; 2.020 .000 kişi işle ilgili hastalıklardan, 321.000 kişi iş kazalarında dolayı ölmektedir. Yılda 160 milyon ölümcül olmayan işle ilgili hastalık, 317 milyon ölümcül olmayan iş kazası belirlenmektedir. İş Kazaları ve İşe Bağlı Sağlık Problemleri Araştırma Sonuçlarına (2013) göre tarım sektöründe iş kazası geçirme/işe bağlı sağlık sorunu \% 2 olarak belirlenmiştir.9,10

Tarımda kullanılan aletlerin çeşitliliği, bununla beraber bir kişinin birden fazla işi yapması, açık havada çalışma ve iklim koşulları gibi faktörler tarım sektöründe çalışma süresini ve dönemini etkilemektedir. Çalışanların çoğunluğunun eğitimsiz olması gibi nedenlerden dolayı tarım sektörünü diğer sektörlerden farklılık göstermektedir. Ayrıca çalışma ortamlarında var olan fiziksel, kimyasal, biyolojik, ergonomik ve psikososyal faktörler tarım çalışanlarının iş kazası geçirme ve meslek hastalıklarına yakalanma risklerini artırmaktadır. ${ }^{2,11-13}$

Bu çalışmada Niğde ili Çiftlik ilçesinde yerleşik olarak tarım işçiliği yapanlarda iş kazası ve zirai ilaçlama ilgili bilgi, tutum ve davranışlarını değerlendirilmesi amaçlanmıştır.

\section{GEREÇ ve YÖNTEM}

Tanımlayıcı ve kesitsel nitelikte olan araştırma, 2017 yılı Temmuz - Eylül ayları arasında Niğde ili Çiftlik ilçesinde yerleşik olarak tarım işleriyle uğraşanlarda yapılmıştır. Evreni bilinmeyen araştırmada örneklem seçilmemiş olup, katılmayı kabul eden 197 tarım çalışanı çalışma kapsamına alınmıştır. Araştırmanın yapılabilmesi için Erciyes Üniversitesi Tıp Fakültesi Girişimsel Olmayan Klinik Araştırma- 
lar Etik Kurulu'ndan etik onay alınmıştır.

Araştırmada, 7 sorudan oluşan sosyo-demografik özellikler ve 36 sorudan oluşan çalışma yaşamına ait (iş kazası ve zirai ilaçlama) olmak üzere toplamda 43 sorudan oluşan anket formu katılımcılarla yüz yüze görüşme yöntemi ile uygulanmıştır. Araştırmanın verileri bilgisayar ortamında SPSS 15.0 (Chicago, IL, USA) programı ile değerlendirilmiş, istatistiksel analizde yüzde ve frekans dağılımları, aritmetik ortalama, standart sapma hesaplanmış, niteliksel veriler için ki-kare testi yapılmıştır. Yapılan analizlerde $\mathrm{p}$ değerinin $<0,05$ olduğu durumlar istatistiksel olarak anlamlı kabul edilmiştir.

\section{BULGULAR}

Araştırmaya katılanların yaş ortalaması 39,3 $\pm 10,42$, \%24,9'u (49 kişi) 30 yaş altı, \%75,1'i (148 kişi) 30 yaş ve üzeri yaş grubundadır. Katılımcıların \%71,6'sı erkek ve \%92,9'u evlidir. Evli olanların da \%38,3'ü üç ve altında, $\% 61,7$ 'si dört ve üzeri çocuğa sahiptirler. Katılımcıların \%3,5’i, okuma yazma bilmezken, \%74,1'i ilköğretim mezunudur. Katılımcıların, \%14,2'si yeşil kartlı olarak sosyal güvence sahipken, \%31,3’ü herhangi bir sosyal güvencesi sahip değildir (Tablo1).

Katılımcıların, \%85,8'i beş yıl ve daha fazla süredir tarım alanında çalışmaktadır. Katılımcıların \%71,6’sı tarımsal iş makinası kullanmaktadır. Katılımcılar haftada ortalama 4,7 $\pm 1,4$ gün, günde ortalama $5,3 \pm 2,1$ saat çalıştıkların1, günde 2,9 $\pm 1,0 \mathrm{kez}$ mola verdiklerini, bu molaların da

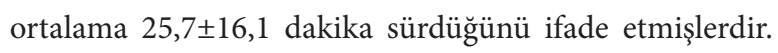
Katılımcıların tamamı işe giriş ve aralıklı periyodik muayene yaptırmamıştır. Sırasıyla toz $(\% 66,5)$, ağırlık kaldırma $(\% 50,2)$ ve gürültü $(\% 36,5)$ en çok şikayet edilen ilk üç çalışma ortamı faktörü olarak bildirilmiştir (Tablo 2).

\begin{tabular}{|l|c|c|}
\hline \multicolumn{3}{|c|}{ Tablo 1. Katılımcıların Sosyo-Demografik Özelliklere Göre Dağılımı } \\
\hline (n=197) & $\mathrm{n}$ & $\%$ \\
\hline Yaş & & \\
$<30$ yaş & 49 & 24,90 \\
$\geq 30$ yaş & 148 & 75,10 \\
\hline Cinsiyet & & \\
Erkek & 141 & 71,60 \\
Kadın & 56 & 28,40 \\
\hline Medeni Durum & 183 & \\
Evli & 14 & 92,90 \\
Bekâr & & 7,10 \\
\hline Çocuk sayısı (n=183) & 70 & \\
$<3$ & 113 & 61,70 \\
$\geq 4$ & & \\
\hline Eğitim Durumu & 7 & 3,50 \\
Okuryazar değil & 10 & 5,10 \\
Okuryazar & 146 & 74,10 \\
İlköğretim (ilkokul ve ortaokul) & 34 & 17,30 \\
Lise & & \\
\hline Sosyal Güvence & 42 & 31,30 \\
Yok & 28 & 14,20 \\
Yeşil kart & & 64,50 \\
Diğer (SGK, Bağ-kur) & & \\
\hline
\end{tabular}

\begin{tabular}{|c|c|c|}
\hline$(n=197)$ & $\mathrm{n}$ & $\%^{* *}$ \\
\hline $\begin{array}{l}\text { Tarımda çalışma süresi } \\
<5 \text { yıl } \\
\geq 5 \text { yıl }\end{array}$ & $\begin{array}{c}28 \\
169\end{array}$ & $\begin{array}{l}14,20 \\
85,80\end{array}$ \\
\hline $\begin{array}{l}\text { Tarımda yapılan işs } \\
\text { Tarla işi } \\
\text { Hayvancılık } \\
\text { Meyvecilik }\end{array}$ & $\begin{array}{c}177 \\
65 \\
7\end{array}$ & $\begin{array}{c}89,50 \\
33,00 \\
3,50\end{array}$ \\
\hline $\begin{array}{l}\text { Şikâyet edilen iş yeri faktörü } \\
\text { Toz } \\
\text { Ağırlık Kaldırma } \\
\text { Gürültü } \\
\text { Uzun çalışma saati } \\
\text { Sıcaklık }\end{array}$ & $\begin{array}{c}131 \\
99 \\
72 \\
44 \\
24\end{array}$ & $\begin{array}{l}66,50 \\
50,20 \\
36,50 \\
22,30 \\
12,20\end{array}$ \\
\hline \multicolumn{3}{|c|}{ İşe girişte muayene yaptırma durumu } \\
\hline $\begin{array}{l}\text { Yok } \\
\text { Var }\end{array}$ & $\begin{array}{l}197 \\
0,0\end{array}$ & $\begin{array}{c}100,0 \\
0,00\end{array}$ \\
\hline \multicolumn{3}{|c|}{ Periyodik muayene yaptırma durumu } \\
\hline $\begin{array}{l}\text { Yok } \\
\text { Var }\end{array}$ & $\begin{array}{c}100,0 \\
0,0\end{array}$ & $\begin{array}{c}100,00 \\
0,00\end{array}$ \\
\hline$(\mathrm{n}=197)$ & $\mathrm{n}$ & $\%^{* *}$ \\
\hline $\begin{array}{l}\text { Günlük çalışma süresi } \\
<8 \text { saat } \\
\geq 8 \text { saat }\end{array}$ & $\begin{array}{c}130 \\
67\end{array}$ & $\begin{array}{l}66,00 \\
34,00\end{array}$ \\
\hline $\begin{array}{l}\text { Haftalık çalışma süresi } \\
<4 \text { gün } \\
\geq 4 \text { gün }\end{array}$ & $\begin{array}{c}37 \\
160\end{array}$ & $\begin{array}{l}18,80 \\
81,20\end{array}$ \\
\hline $\begin{array}{l}\text { Günlük verilen mola sayısı } \\
<4 \mathrm{kez} \\
\geq 4 \mathrm{kez}\end{array}$ & $\begin{array}{c}152 \\
45\end{array}$ & $\begin{array}{l}77,20 \\
22,80\end{array}$ \\
\hline $\begin{array}{l}\text { Verilen mola süresi (Dakika) } \\
<20 \text { dakika } \\
\geq 20 \text { dakika }\end{array}$ & $\begin{array}{c}89 \\
108\end{array}$ & $\begin{array}{l}45,20 \\
54,80\end{array}$ \\
\hline
\end{tabular}




\begin{tabular}{|c|c|c|}
\hline$(n=197)$ & $\mathrm{n}$ & $\%^{* *}$ \\
\hline $\begin{array}{l}\text { Zirai ilaçlama yapma durumu } \\
\text { Evet } \\
\text { Hayır }\end{array}$ & $\begin{array}{c}107 \\
90\end{array}$ & $\begin{array}{l}54,30 \\
45,70\end{array}$ \\
\hline $\begin{array}{l}\text { İlaçlama yapma süresi }(\mathrm{n}=107) \\
<5 \text { y1l } \\
\geq 5 \text { yil }\end{array}$ & $\begin{array}{l}14 \\
93\end{array}$ & $\begin{array}{l}13,10 \\
86,90\end{array}$ \\
\hline $\begin{array}{l}\text { Zirai ilaçlama öncesi/sırası/sonrasında yapılanlar } \\
(\mathrm{n}=107)^{*} \\
\text { Eldiven giyme } \\
\text { İlaçlama sonrası duş alma } \\
\text { İlaçlamada sonra el ve yüz yıkama } \\
\text { İlaçlamada önce saçlarını kapatma } \\
\text { Maske takma } \\
\text { İlaçlama kıyafetlerini diğer çamaşırlardan ayrı } \\
\text { yıkama } \\
\text { Tulum giyme } \\
\text { Hiçbiri }\end{array}$ & $\begin{array}{c}69 \\
46 \\
24 \\
21 \\
18 \\
\\
14 \\
7 \\
13\end{array}$ & $\begin{array}{c}64,50 \\
43,00 \\
22,40 \\
19,60 \\
16,80 \\
\\
13,10 \\
6,50 \\
12,10\end{array}$ \\
\hline $\begin{array}{l}\text { Zirai ilaçlama esnasında/sonrasında sağlık sorunu } \\
\text { yaşama*** } \\
\text { Evet } \\
\text { Hayır }\end{array}$ & $\begin{array}{l}39 \\
89\end{array}$ & $\begin{array}{l}30,50 \\
69,50\end{array}$ \\
\hline $\begin{array}{l}\text { Yaşanan sağlık sorunları }(\mathrm{n}=39)^{*} \\
\text { Baş ağrısı } \\
\text { Halsizlik } \\
\text { Göz yanması } \\
\text { Yorgunluk } \\
\text { Bulantı } \\
\text { Bulanık görme } \\
\text { Uyku hali }\end{array}$ & $\begin{array}{l}20 \\
14 \\
14 \\
11 \\
7 \\
7 \\
7\end{array}$ & $\begin{array}{l}51,30 \\
35,90 \\
35,90 \\
28,20 \\
17,90 \\
17,90 \\
17,90\end{array}$ \\
\hline $\begin{array}{l}\text { Zirai ilaçlamanın zararlarını bilme durumu } \\
\text { Evet } \\
\text { Hayır }\end{array}$ & $\begin{array}{c}162 \\
35\end{array}$ & $\begin{array}{l}82,20 \\
18,80\end{array}$ \\
\hline $\begin{array}{l}\text { Zirai ilaçlamanın zararları* } \\
\text { Zehirlenme } \\
\text { Kanser } \\
\text { Düşük/ölü doğum } \\
\text { Engelli/sakat bebek doğumuna } \\
\text { Hormonları bozar } \\
\text { Kansızlık }\end{array}$ & $\begin{array}{c}162 \\
69 \\
42 \\
21 \\
21 \\
7\end{array}$ & $\begin{array}{l}82,20 \\
35,00 \\
21,30 \\
10,60 \\
10,60 \\
3,50\end{array}$ \\
\hline
\end{tabular}

Katılımcıların \%54,3’ü ortalama 9,0 0 6,5 yıldır zirai ilaçlama yaptığını ifade etmişlerdir. Zirai ilaçlama öncesinde katılımcıların \%64,5 eldiven giydiğini, \%19,6'sı saçlarını kapattığını, \%16,8'i zirai ilaçlama esnasında maske taktığını, \%43,0’ü zirai ilaçlama sonrasında duş aldığını ifade etmiştir. Katılımcıların \%13,0 ${ }^{\prime} u ̈$ ise zirai ilaçlama öncesi, sırası ve sonrasında hiçbir şey yapmadığını ifade etmişlerdir. Zirai ilaçlama yapanlar ve zirai İlaçlama esnasında yanında bulunanların oranı \%30,5'dir. Baş ağrısı $(\% 51,3)$, halsizlik $(\% 35,9)$ ve göz yanması $(\% 35,9)$ zirai ilaçlama esasında ve sonrasında en çok şikayet yaratan sağlık sorunları olarak bildirilmiştir. Katılımcıların \%82,2'si zirai ilaçlamanın insan sağlığına zarar verebileceğini, zehirlenmelere $(\% 82,2)$, kansere $(\% 35,0)$, ölü doğuma ve düşüklere $(\% 21,3)$ neden olabileceğini düşünmektedirler (Tablo 3).

Katılımcıların \%17,3'ü çalışma hayatı boyunca en az bir kere iş kazası geçirmiştir. Motorlu tarım makinalarından ve elle kullanılan basit aletlerden kaynaklanan $(\% 64,0)$, düşme ve çarpmalar $(\% 14,7)$ ve taşıtların neden olduğu kazalar $(\% 11,5)$ en çok iş kazasına neden olan durumlardır. 14 kişide $(\% 41,2)$ iş kazası sonucunda kalıcı bir durum oluşmuştur. Katılımcıların \%93,0’ı dikkatsizliğin, \%50,3’ü yapılan işle ilgili bilgisizliğin en sık iş kazası nedeni olabileceğini ifade etmişlerdir. İşle ilgili en sık kullanılan üç kişisel koruyucu sırasıyla; eldiven $(\% 86,8)$, şapka/baret $(\% 71,1)$ ve özel ayakkabı/çizme $(\% 20,8)$ olmuştur. Kat1lımcıların sadece $\% 3,6$ ’sı işle ilgili bir eğitim ve ilkyardım eğitimi almışlardır (Tablo 4).

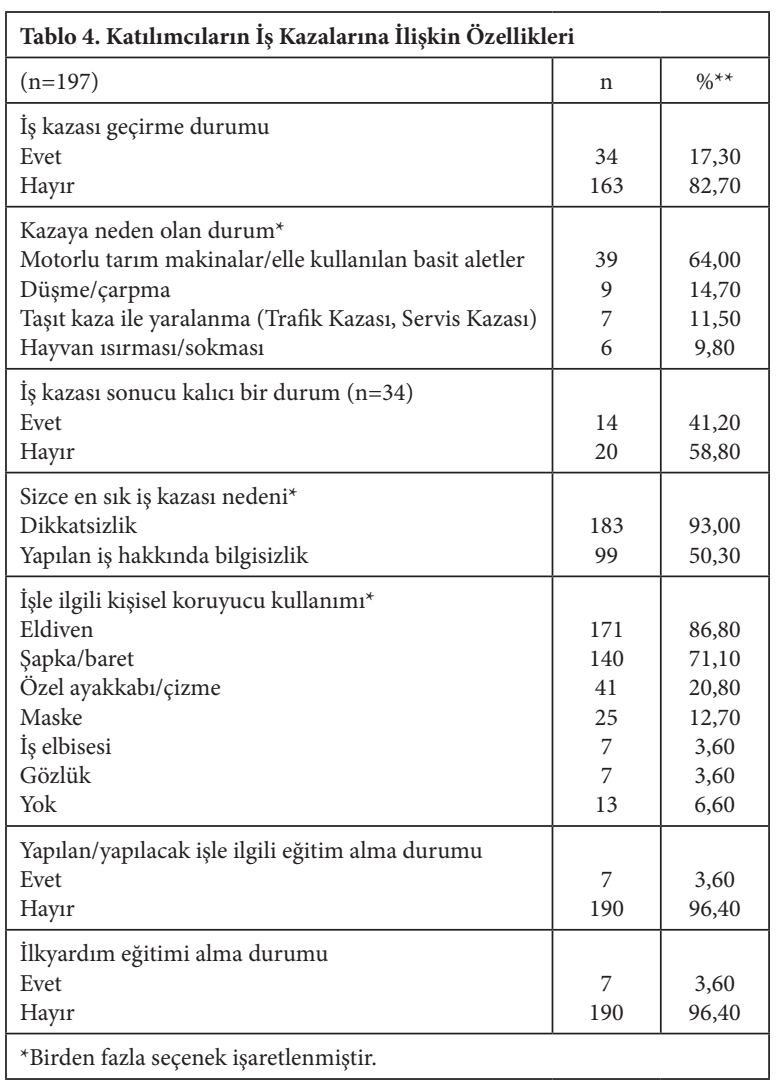


Katılımcıların \%17,3’ü iş kazası geçirmiştir. İş kazasına maruz kalanların \%61,8'i kadın, \%79,4'ü 30 yaş altındadır. Kadınların \%37,5'i, erkeklerin de \%9,2'si iş kazası geçirmiştir ve aradaki fark istatistiksel olarak anlamlıdır $(\mathrm{p}<0,01)$. Günlük çalışma süresi 8 saat ve üzerinde olan- larda $(\% 37,3)$, zirai ilaçlama esnasında/sonrasında sağlık sorunu yaşayanlarda $(\% 64,1)$ iş kazası daha yüksek ve aradaki farklar da istatistiksel olarak anlamlıdır ( $\mathrm{p}<0,01)$. İş kazalarının tamamı tarımda çalışma süresi beş yıl ve üzeri olanlarda görülmektedir (Tablo 5).

\begin{tabular}{|c|c|c|c|c|c|c|c|c|}
\hline \multirow[t]{3}{*}{ Değişkenler } & \multicolumn{4}{|c|}{ İş Kazası Geçirme Durumu } & \multirow{2}{*}{\multicolumn{2}{|c|}{ Toplam }} & \multirow{3}{*}{$\mathrm{X}^{2}$} & \multirow{3}{*}{$\mathrm{p}$} \\
\hline & \multicolumn{2}{|c|}{ Geçirmiş } & \multicolumn{2}{|c|}{ Geçirmemiş } & & & & \\
\hline & $\mathrm{n}$ & $\%$ & $\mathrm{n}$ & $\%$ & $\mathrm{n}$ & $\%$ & & \\
\hline $\begin{array}{l}\text { Cinsiyet } \\
\text { Erkek } \\
\text { Kadın }\end{array}$ & $\begin{array}{l}13 \\
21\end{array}$ & $\begin{array}{c}9,20 \\
37,50\end{array}$ & $\begin{array}{c}128 \\
35\end{array}$ & $\begin{array}{l}90,80 \\
63,50\end{array}$ & $\begin{array}{c}141 \\
56\end{array}$ & $\begin{array}{l}100,00 \\
100,00\end{array}$ & 22,448 & 0,000 \\
\hline $\begin{array}{l}\text { Yaş } \\
<30 \text { yaş } \\
\geq 30 \text { yaş }\end{array}$ & $\begin{array}{c}7 \\
27\end{array}$ & $\begin{array}{l}14,30 \\
18,20\end{array}$ & $\begin{array}{c}42 \\
121\end{array}$ & $\begin{array}{l}85,70 \\
81,80\end{array}$ & $\begin{array}{c}49 \\
148\end{array}$ & $\begin{array}{l}100,00 \\
100,00\end{array}$ & 0,404 & 0,525 \\
\hline $\begin{array}{l}\text { Tarımda Çalışma süresi } \\
<5 \text { yıl } \\
\geq 5 \text { yll }\end{array}$ & $\begin{array}{c}0 \\
34\end{array}$ & $\begin{array}{c}0,00 \\
20,10\end{array}$ & $\begin{array}{c}28 \\
135\end{array}$ & $\begin{array}{c}100,00 \\
79,90\end{array}$ & $\begin{array}{c}28 \\
169\end{array}$ & $\begin{array}{l}100,00 \\
100,00\end{array}$ & 11,538 & 0,001 \\
\hline $\begin{array}{l}\text { Tarımsal makine kullanr } \\
\text { Evet } \\
\text { Hayır }\end{array}$ & $\begin{array}{l}20 \\
14\end{array}$ & $\begin{array}{l}14,20 \\
25,00\end{array}$ & $\begin{array}{c}121 \\
42\end{array}$ & $\begin{array}{l}85,80 \\
75,00\end{array}$ & $\begin{array}{c}141 \\
56\end{array}$ & $\begin{array}{l}100,00 \\
100,00\end{array}$ & 3,283 & 0,070 \\
\hline $\begin{array}{l}\text { Zirai ilaçlama esnasında } \\
\text { yaşama } \\
\text { Evet } \\
\text { Hayır }\end{array}$ & $\begin{array}{c}25 \\
9\end{array}$ & $\begin{array}{l}64,10 \\
10,10\end{array}$ & $\begin{array}{l}14 \\
80\end{array}$ & $\begin{array}{l}35,90 \\
89,90\end{array}$ & $\begin{array}{l}39 \\
89\end{array}$ & $\begin{array}{l}100,00 \\
100,00\end{array}$ & 40,522 & 0,000 \\
\hline $\begin{array}{l}\text { Günlük çalışma süresi } \\
<8 \text { saat } \\
\geq 8 \text { saat }\end{array}$ & $\begin{array}{c}9 \\
25\end{array}$ & $\begin{array}{c}6,90 \\
37,30\end{array}$ & $\begin{array}{c}121 \\
42\end{array}$ & $\begin{array}{l}93,10 \\
62,70\end{array}$ & $\begin{array}{c}130 \\
67\end{array}$ & $\begin{array}{l}100,00 \\
100,00\end{array}$ & 28,595 & 0,000 \\
\hline
\end{tabular}

TARTIŞMA

Çalışmamızda katılımcıların \%17,3’ü iş kazası geçirmiştir. ILO tahminlerine göre; çalışma yaşamında yıllık 2,31 milyon kaza ve hastalık görülmekte (358.000 ölümcül kaza, 1,95 milyon işle ilgili hastalık), bunların yaklaşık yarısı tarımda gerçekleşmektedir. ${ }^{14}$ Sosyal Güvenlik Kurumu (SGK) 2015 yılı verilerine göre tarım sektöründe 1719 kişinin iş kazası geçirdiği görülmektedir. ${ }^{15}$ Ülkemizde mevsimlik tarım işçilerine yönelik Ankara ile Polatlı ilçesinde $(\% 41,8)$, Şanlıurfa/Adıyaman illerinde $(\% 52,8)$ ve Adana ilinde $(\% 53,8)$ yapılan çalışmalarda iş kazası/işle ilgili hastalık geçirdiği belirlenmiştir. ${ }^{16-18}$ İş kazaları ile ilgili oranlar arasındaki farklılık tarım sektöründe kayıt dışı istihdamın çok olması ve iş kazası sayılarının da tam olarak gerçeği yansıtmadığından kaynaklanabilir.

Zirai ilaçlar, toprak ve su kaynakları yoluyla çevre kirliliğini artırarak dolaylı yolla insan sağlığı üzerinde olumsuz yönde etkilenmektedir. Ayrıca zirai ilaçlamanın bilinçsiz uygulanması, uygulama esnasında kişisel koruyucuların kullanılmaması ve uygunsuz şekilde depolanmasıyla da direk olarak insan sağlığı üzerinde olumsuz yönde etkilenmektedir. ${ }^{3}$ Dünyada her yıl yaklaşık 1 ile 5 milyon arasında insanın zehirlenmesine neden olan zirai ilaçlamanın oluşturduğu sağlık etkileri akut ve kronik olmak üzere iki başlık altında incelenebilir. Akut maruziyet; irritasyon, dermatit gibi alerjik reaksiyonlar oluşturmaktadır. Kronik maruziyet; gelişimsel, üreme, immün sistem, endokrin ve 
sinir sistemi fonksiyonlarının bozulması ile ilişkili hastalıklar ve kanser gelişimi için artmış risk oluşturur. ${ }^{22-25}$

Çalışmamızda katılımcılar zirai ilaçlamanın insan sağlığına zararları ile ilgili zehirlenme, kanser, düşük/ölü doğum, engelli/sakat bebek doğumu, hormonal dengesizlik ve kansızlık gibi sağlık etkileri oluşturabileceğini ifade etmişlerdir. Bir derleme çalışmasında, zirai ilaçlama kullanımı sırasında veya sonrasında, akut maruziyet belirtilerinin yaygın (\%20-70) olarak görüldüğü tespit edilmiştir. ${ }^{26}$

Çalışmamızda katılımcıların \%54,3’ü zirai ilaçlama yaptığını, zirai ilaçlama öncesi/sırası/sonrasında; saçlarını kapatma, eldiven giyme, ilaçlama sonrası el, yüz yıkama ve duş alma gibi önlemler aldıklarını ifade etmişlerdir. Zirai ilaçlama ile ilgili bir derleme çalışmasında; tarım çalışanları tarafından zirai ilaçlama ile ilgili korunma ve hijyen kurallarına yeterince uyulmadığı (uygulama sonrası el yıkama \%60-100, tüm vücut temizliği yapma \%33-91), kişisel koruyucu donanım kullanımının (\%31-93) düşük olduğu tespit edilmiştir. ${ }^{26}$ Tarım çalışanlarının zirai ilaçlamanın insan sağlığına etkileri hakkında bilgileri olmasına rağmen zirai ilaçlama öncesi/sırası/sonrasında yapılması gerekenler ile ilgili uygulamada eksikliklerinin olduğu söylenebilir.

Mütevellioğlu'nun yaptığı çalışmada; iş kazası riskinin günlük çalışma süresi paralellik gösterdiği bulunmuştur. ${ }^{20}$ Amerika Birleşik Devletleri'nde (ABD) yapılan kapsamlı bir çalışmada, fazla çalışma yapılan işlerde kaza risk oranının daha yüksek olduğu bulunmuştur. ${ }^{21}$ Çalışmamızda günlük çalışma süresi 8 saat ve üzeri olanlarda iş kazası geçirme durumu, günlük çalışma süresi 8 saat altında olanlara göre daha yüksektir ve aradaki fark istatistiksel olarak anlamlıdır $(\mathrm{p}<0,01)$. Çalışma süresinin aşıldığı durumlarda, fiziki ve ruhsal yönden bozulmalara neden olabilir. Böyle bir durumda yorgunluğa ve işe olan konsantrasyonunun düşmesine neden olabilir. Çalışanların psikolojik ve fizyolojik yönden olumsuz etkilenimlerinin yanı sıra, hata yapma riski de artırabilir.
Adana'da mevsimlik tarım işçilerinde yapılan çalışmada, çalışma yılı artıkça iş kazası/işle ilgili hastalık geçirme durumunun artığı tespit edilmiştir. Kayseri'de mesleki eğitim merkezi öğrencilerinde yapılan çalışmada çalışma yılı artıkça iş kazası geçirme durumu artmıştır. ${ }^{16,19}$ Çalışmamızda, çalışma yılı 5 yıldan fazla olanların iş kazası geçirme durumunun istatistiksel olarak anlamlı şekilde daha yüksek olduğu bulunmuştur. Çalışmamızda, yaşı 30 ve üzeri olanlarda iş kazası geçirme durumu 30 yaş altındakilere göre daha yüksek bulunmuştur. Çalışanlarda yaş ve çalışma yılının fazla olması, çalışanların daha tecrübeli ve deneyimli olarak nitelendirilebilir. Bu durum, yaş ve çalışma yılı fazla olan çalışanların tehlikeli ve riskli işlerde daha fazla tercih edilmelerine neden olabilir. Ayrıca deneyim ile bağlantılı olarak özgüvenin daha fazla olması, dikkatsizliğin artmasına ve sonuç olarak iş kazalarına sebep olabilir. Katılımcılara göre de en sık iş kazası nedeni olarak ifade edilen "dikkatsizlik" ile iş kazaları arasında bağlantı kurulabilir.

\section{SONUÇ ve ÖNERİLER}

Çalışmamızda, yaklaşık her beş yerleşik tarım çalışanından birisi iş kazası olarak değerlendirilebilecek bir olumsuzluk yaşamıştır. Tamamına yakını zirai ilaçlama ve rutin olarak diğer çeşitli tarımsal uygulamalar konusunda resmi hiçbir eğitim almamışlardır. Yerleşik tarım çalışanları herhangi bir şirket, kuruluş vb. bünyesinde değil de kendi adlarına çalıştıkları için yürürlükteki iş sağlığı ve güvenliği mevzuatı çerçevesinde yasal yükümlülükleri bulunmamaktadır. $\mathrm{Bu}$ olumsuz durumun düzeltilebilmesi için sektörler arası (yerel yönetimler, tarım ve hayvancılık müdürlükleri, kooperatifler, odalar vb.) işbirliği yapılarak gerekli yasal düzenlemeler gerçekleştirilmeli ve yerleşik tarım çalışanlarının iş sağlığı ve güvenliği hizmetlerinden yararlanmaları sağlanmalıdır. 
Sakarya Tip Dergisi 2019;9(4):632-638

DOĞAN ve Ark., Tarım Çalıșanlarında Zirai İlaçlama ve İș Kazası

\section{Kaynaklar}

1. Menemencioğlu K. Tarım ve Orman İş̧̧iliğinde Çalșma Yeri Koșulları ve Karşıllaşıllan Sorunlar. Türk Bilimsel Derlemeler Dergisi 2012; 5(2): 72-76.

2. Bakırcı N. Tarımda Çalışanların Sağlığı ve Güvenliği. Türk Tabipleri Birliği Mesleki Sağlık ve Güvenlik Dergisi 2011; 39: 7-13.

3. Eren Yalçın G, Yazıcı E, Öcal Kara F. Tarımda İs Kazaları ve Hastalıkları. XII. Tarım Ekonomisi Kongresi, 2049-2056

4. http://www.tuik.gov.tr/UstMenu.do?metod=temelist (Erişim Tarihi: 29.05.2019)

5. http://www.tuik.gov.tr/PreHaberBultenleri.do?id=30709 (Erișim Tarihi: 29.05.2019)

6. http://www.tuik.gov.tr/PreHaberBultenleri.do?id=30690 (Erişim Tarihi: 29.05.2019)

7. http://www.fao.org/3/y4544e/y4544e02.htm\#bm2.1 (Erişim Tarihi: 07.11.2019)

8. 5510 sayıl Sosyal Sigortalar ve Genel Sağlk Sigortası Kanunu 31/5/2006 http://www.resmigazete.gov.tr/eskiler/2006/06/20060616-1.htm (Erişim Tarihi: 29.05.2019)

9. https://www.ilo.org/global/about-the-ilo/newsroom/news/WCMS_211627/lang-en/index. htm (Erişim Tarihi: 10.06.2019)

10. http://tuik.gov.tr/PreHaberBultenleri.do?id=16118 (Erişim Tarihi: 29.05.2019)

11. https://www.csgb.gov.tr/media/4604/rehber27.pdf (Erişim Tarihi:10.06.2019)

12. Rehber E. Tarımda Endüstrileșme ve Küreselleșme. İktisat Dergisi 2006; 477: 20-25.

13. http://www.mevsimliktarimiscileri.com/sayfadetay.aspx?id=117. (Erişim Tarihi: 20.05.2019)

14. International Labour Organization. 2010 World Day for Safety and Health at Work; Emerging risks and new patterns of prevention in a changing world of work, 2010, Geneva. http:// www.ilo.org/safework/info/publications/lang--en/docName--WCMS_123653/index.htm (Erişim Tarihi:10.06.2019)

15. http://www.sgk.gov.tr/wps/portal/sgk/tr/kurumsal/istatistik/sgk_istatistik_yilliklari (Erișim Tarihi: 29.05.2019)

16. Gönültaş T, Aytaç N, Akbaba M. Mevsimlik Tarım İş̧ilerinin İș Kazası ve İşle İlgili Hastallk Geçirme Durumlarının Araștırılması. Sakarya Tip dergisi 2018; 8(1):117-126.
17. Şimșek Z. Mevsimlik Tarım İșçilerinin ve Ailelerinin İhtiyaçlarının Belirlenmesi Araștırmas 2011. Harran Üniversitesi Tip Fakültesi Halk Să̆lğ̆ı Anabilim Dalı Ve Birleşmiş Milletler Nüfus Fonu 2012. Ankara

18. Erbörü N. Ankara İli Polatl İlçesi Sarıba Köyündeki Mevsimlik Tarım İş̧̧ilerinde İș Kazası Sıklı̆̆ ve İlişkili Etmenler. Yüksek Lisans Tezi, İş Sağllğı Ve Güvenliği Anabilim Dalı Gazi Universitesi Sağlk Bilimleri Enstitüsü 2014.

19. Doğan M, Gün İ, Șenol V. Mesleki Eğitim Merkezi Öğrencilerinde İş Kazast Sıklı̆ı ve Etkileyen Etmenler. Sağllk Bilimleri Dergisi (Journal of Health Sciences) 2018; 27 (1): 22-28.

20. Mütevellioğlu N. Türkiye’de çalışma sürelerinin uzaması ve ölümlü iş kazalarında artıș. Mesleki Sağllk ve Güvenlik Dergisi 2009; 32: 8-14.

21. Dembe AE, Erickson JB, Delbos RG, Banks SM. The impact of overtime and long work hours on occupa-tional injuries and illnesses: new evidence from the United States. Occup Environ Med 2005; 62: 588-597.

22. World Health Organization (WHO)/ United Nations Environment Programme (UNEP). Toxic Hazard. http://www.who.int/heli/risks/ toxics/chemicals/en/index.html (Erișim tarihi: 10.06.2019).

23. Piyal B. (çev ed.) Tarımda Güvenlik ve Sağllk (Uluslararası Çalıșma Örgütü Düzenlemeleri). Ankara: T.C. Çalışma ve Sosyal Güvenlik Bakanlı̆̆ı, Çalışma ve Sosyal Güvenlik Ĕ̆itim ve Araștırma Merkezi (CASGEM), Ankara, 2013.

24. World Health Organization (WHO). Public health impact of pesticides used in agriculture. Geneva: World Health Organization, 1990.

25. Çamurcu S, Seyhan TG. Tarım Sektöründe İș Sağlğ̆ı ve Güvenliği. Süleyman Demirel Üniversitesi Mühendislik Bilimleri ve Tasarım Dergisi 2015; 3(3): 549-552.

26. Uskun E. Tarım çalı̧sanlarının bitki koruma ürünleri konusunda bilgi ve davranışları. Turk Hij Den Biyol Derg, 2015; 72(3): 241-54. 